ment]. Aktual'ni problemy kryminal'noho prava, protsesu ta kryminalistyky: mater. II Mizhnar. nauk.prakt. konf. (m. Odesa, 8 zhovtnya 2010 r.). Odesa : PP «Feniks», S. 208-211.

13. Mitrofanov, I. I. (2009) Zahal'na kharakterystyka ta vydy zlochyniv u sferi hospodars'koyi diyal'nosti [General characteristics and types of crimes in the field of economic activity]. Visnyk Kremenchuts'koho derzhavnoho politekhnichnoho universytetu. № 4. S. 154-157.

\title{
Summary
}

There is the analysis of the mechanism of criminal legal regulation from the point of view of its structure. The key categories of this mechanism have been considered - the rules of criminal law and criminal law relations.

The importance of the mechanism of criminal law regulation for law-making is shown through concrete examples of legislative novelties.

Keywords: criminal law norms, criminal law relations, mechanism of criminal law regulation, lawmaking, legal facts, mutual rights and obligations, subjects of criminal legal relations.

UDC 343.232

DOI 10.31733/2078-3566-2019-5-183-189

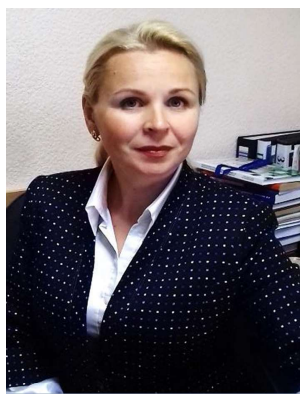

Hanna FEDOTOVA ${ }^{\circledR}$

Dr of Law, Sr Research Fellow (State Research Institute of the Ministry of Internal Affairs of Ukraine)

\section{CRIMINAL AND LEGAL ESSENCE OF THE «CRIMINAL OFFENSE» CATEGORY}

Ганна Федотова. КРИМІНАЛЬНО-ПРАВОВА СУТНІСТЬ КАТЕГОРІї «КРИМІНАЛЬНИЙ ПРОСТУПОК». 3 метою визначення кримінально-правової сутності категорії кримінальний проступок проаналізовано дефініцію «кримінальне правопорушення» як родового (дочірнього) поняття та охарактеризовано видові (похідні) поняття «злочин» та «кримінальний проступок». Розкрито усвідомлення сутності явища «кримінальний проступок» в кримінальноправовій науці за результати якої доведено притаманність злочинної природи кримінальному проступку.

Зазначено, що, незважаючи на те, що вчені-правознавці достатньо давно вивчають проблеми кримінальних проступків, в усвідомленні сутності цього явища в кримінально-правовій науці та практиці бракує одностайності.

На підставі аналізу думок науковців зроблено висновок, що термін «проступок» здебільшого використовується як тотожне при визначенні правопорушення, без якогось змістового розмежування. Таке ототожнення, на нашу думку, некоректне, оскільки правопорушення $є$ більш загальним поняттям та за чинним законодавством охоплює всі види проступків і злочини.

Наголошено на притаманності кримінальному проступку злочинної природи, підтвердженням чого є прийняття 22 листопада 2018 року Верховною Радою України Закону України «Про внесення змін до деяких законодавчих актів України щодо спрощення досудового розслідування окремих категорій кримінальних правопорушень» (№7279-д). Після набуття ним чинності 1 вересня 2020 р. буде введено в дію положення щодо урегулювання питання кримінальних проступків, наділяючи вказану категорію статусом одного 3 видів кримінального правопорушення, за яке передбачено кримінальну відповідальність, використовуючи при цьому виокремлюючи критерії - ступінь суспільної небезпеки, вид і міру покарання. Відповідно до положень Закону «кримінальним проступком» $є$ передбачене Кримінальним кодексом діяння (дія чи бездіяльність), за вчинення якого передбачене основне покарання у виді штрафу в розмірі не більше трьох тисяч неоподатковуваних мінімумів доходів громадян або інше покарання, не пов'язане $з$ позбавленням волі.

Ключові слова: кримінальне правопорушення, злочин, кримінальний проступок, кримінальне прочесуальне законодавство, кримінальне законодавство.

Problem statement. With the adoption of the Criminal Procedure Code of Ukraine in 2012 (hereinafter referred to as the CPC), in addition to the «crime», the only criminal, socially dangerous and harmful act for which criminal liability may occur, such concept as «criminal

(C) Fedotova H., 2019

ORCID iD: https://orcid.org/0000-0002-7798-3143

dndi@mvs.gov.ua 
misconduct», which have a lower degree of public danger, a simplified prosecution process, and softer punishments. In addition, the CPC introduced the concept of «criminal offenses», which encompassed all criminal offenses that, so to speak, are divided into crimes and criminal offenses. Thus, the concept of «criminal offense» actually captured the place of the generic (child) concept to refer exclusively to the specific concepts of «crime» and «criminal misconduct». The definition of the conceptual apparatus and the investigation of the category of criminal offense in the doctrine of criminal law should be carried out through the analysis of the concept of «criminal offense» enshrined in criminal procedural law, which covers both crime and criminal offense [1].

The article's objective. Let's try to reveal the essence of the concept of «criminal offense» by defining the components of this phenomenon.

Basic content. «Crime» is one of the fundamental categories of criminal law, the key concept in this field of law, which underlies all other criminal concepts and institutions. This word is formed from the noun «evil» and the verb «to do» and means «to commit evil», «to do evil» [2, p. 267; 3, c. 605]. Crime, like any other offense, is the act of a person, moreover, by its very nature, is an attack on those relations which have developed in the society, reflecting its most important interests, that is why they are protected by the law on criminal liability.

The concept of crime is derived from crime. In a concise form, crime is a social phenomenon, a process, a state, a pattern, and the totality of crimes committed. Ya. I. Glinsky [4, p. 32] regards «crime» and «criminality» as relative and conventional concepts that partially reflect some of the social realities. For understanding the nature of crime, I. I. Karpets emphasizes [5, p. 87], it is important to keep in mind that it reflects the particular contradictions and deformations of social being. To some extent, they are right, it is common for society to determine crime and punishment without worrying about the consequences. Thus, in Soviet times in the 1930's there was a period when criminal liability was imposed for abortion [6], in the course of time the criminal liability of pregnant women for abortion was abolished and it concerned only the persons (including doctors) who performed abortions outside hospitals or other medical institutions $[7 ; 8]$. The similar example in the times of independence of our country is the adoption of the Law of Ukraine «On Amendments to the Criminal Code of Ukraine on Improving Responsibility for Trafficking in Persons and Engaging in Prostitution» dated January 12, 2006, No. 3316-IV, which abolished criminal liability of a person for systematic engagement in prostitution (provision of sexual services) and established responsibility for pimping or involving a person in prostitution (Article 303 of the Criminal Code of Ukraine) [9]. But the question arises as to the public danger of this act. It cannot appear and disappear depending on the will of the legislator. Defining a person's behavior as a crime (criminalizing an act) or excluding it from the range of criminal acts (decriminalizing an act) is a continuous process of assessing the conformity or non-conformity of that behavior with social development.

According to some scholars, social danger is a social feature characteristic only of crimes $[10 ; 11$, c. $74 ; 12$, c. 8$]$.

At the same time, opinions are expressed about the unity of all offenses, including crimes, which is social in nature - their social danger, and the difference is only due to a different degree of this social danger $[13 ; 14 ; 15 ; 16$, c. $17 ; 17 ; 18$, c. 115$]$.

Crimes are inherent in the greatest danger due to the object of the attack, the nature and gravity of the harm, the mode of action, the form and degree of the fault, the motives and purpose, as well as all other objective and subjective features. There is no clear opinion as to the concept and content of public danger. Public danger refers to a material sign (an intrinsic property) of a criminal act that reveals its social essence, enshrined in law, and has legal significance.

The degree of public danger is conditioned by the presence or absence of certain signs that affect public danger, with neither the legislator nor the law enforcement body having the ability to influence the public danger of action. That is, danger is inherent in action not because it has been so appreciated by someone, but because it inherently contradicts the normal conditions of existence of this society, and encroaches on publicly protected relationships. For example, paying a debt to a debtor is a civil legal relationship, but if you look at it in detail and find out that the intention to misappropriation was formed long before they were borrowed, it already forms a crime - fraud.

S. V. Kivalov [19] spoke his mind about the system of public danger in the context of the substitution of the term «crime» for «criminal offense», proposing to define «criminal offense as a socially dangerous, harmful, criminal unlawful act (act or omission) of the subject of criminal offense, and criminal misconduct - as a type of criminal offense that has a reduced 
degree of public danger that does not lead to criminal convictions. In this sense, the signs of criminal misconduct are due not only to the absorption of many (disciplinary, administrative, civil) offenses by crime, but also to the social characteristics of encroachment on basic social values».

Despite the fact that legal scholars have long been studying the problems of criminal misconduct, there is a lack of unanimity in the awareness of the essence of this phenomenon in criminal science and practice.

The scientific and practical significance of this problem is determined by the need to update opinions on criminal offenses, which is caused by the emergence of new state priorities, reform of criminal justice, refocusing on other, more sophisticated and free methods of legal regulation.

The term «misconduct» is multifaceted in its meaning and is used in different meanings and contexts.

Many scholars have considered the definition of criminal misconduct in their works, including I. P. Golosnichenko, M. M. Dmitruk, O. O. Kashkarov, O. D. Kos, A. A. Manzhula, L. V. Pavlik, S. V. Petkov, V. O. Tuliakov, P. L. Fris and others. However, there is no clear understanding of the legal nature and definition of the specific concept that would reveal the nature of the criminal offense.

For this purpose, it is logically to pay attention to the linguistic aspect, which, above all, will help to clarify the legal meaning of the term "misconduct". According to the etymology, misconduct is defined as «sin», guilt or «lech» [20, v. 1, p. 328, v. 3, p. 2010]. Modern dictionaries of the Ukrainian language reveal misconduct as an act that violates any norms, rules of conduct, generally accepted order; guilt [21, p. 306; 22, c. 817]. In the general social sense, misconduct means an anti-social or harmful to society action aimed at destroying the foundations of civilized life and violating the norms fixed by the legal codes of the state [23, p. 20]. In a legal encyclopedia, misconduct is considered a crime - a type of offense that is guilty of (or inaction), different from a crime of lesser degree of public danger. One of the measures of public influence for misdemeanor involving a violation of public order is public condemnation, reprimand, fine, and so on; for misconduct in the course of their duties, one of the disciplinary sanctions; for committing an administrative offense - one of the administrative penalties [24, p. 47]. V. V. Kopeychikov defines misconduct as an act that violates the rules of law, but does not reach the level of public danger inherent in crime [25]. Traditional and generally accepted theory of state and law is the opinion according to which the offense is classified into crimes and misdemeanors, depending on the degree of public danger (harm) [26, p. 438-439]. In Soviet law, as stated by S. V. Petkov [27], the definition of misconduct only as an administrative offense was wrong. Such a judgment existed to simplify the activities of the socialist bodies, and therefore all misdemeanors were called offenses and were placed in one code - the Code of Ukraine on Administrative Offenses. According to the above theory, misdemeanor-torts (Latin delictum - misdemeanor) are offenses that cause harm to a person, society, state and are grounds for bringing an offender to the liability provided by law. But misdemeanors should be distinguished from crimes, since a criminal offense is a criminal act envisaged by a socially dangerous act (act or omission), which involves the assault on the social order of the state, its political and economic systems, property, person, political, labor, property and other rights and freedoms of citizens, as well as other socially dangerous act, provided for by the criminal law, which is to encroach on the rule of law. Therefore, the term «misconduct» is mostly used as an identity in defining an offense, without any meaningful delineation. Such an identification is, in our view, incorrect, since offense is a more general concept and covers, under applicable law, all types of misconduct and crime.

There has been widespread debate about the legal content of criminal misconduct among legal scholars. I. P, Golosnichenko [28, p. 70] proposes to refer to the experience of foreign countries and to introduce in Ukrainian legislation the term «criminal misconduct» together with administrative offenses and crimes, motivating it with the conformity of the laws of unlawful acts classification and taking into account all peculiarities of establishing both material and procedural relations. Comparing the definitions of «misdemeanor» and «violation», A. A. Manzhula [29] concludes that the violation is non-compliance with the system of rules, while the misdemeanor is non-compliance with a particular type of specific rule, rules of behavior. Many lawyers claim that the institution of criminal misconduct is an institution of criminal law [30]. Instead, L. Pavlik [31, p. 524] considers it «unconventional» for the field of criminal law. A. D. Kos, defines criminal offense as an element of crime-fighting policy, refer- 
ring to the content of the Concept of Criminal Justice Reform. P. L. Fries is ambiguous in his statements about the wrongdoing [33]. He cites several options, such as: «criminal offenses», «punishable offenses, transgressions» and proposes to use the term «criminal offenses» (which, in our view, is not inherent in this field) in criminal theory, understanding it as socially harmful, unlawful, guilty act (act or omission) committed by a physical or legal entity, as well as by an organizational entity that does not have the status of a legal entity but is empowered to act on its own behalf, for which the Criminal Code provides for liability.

V. O. Tuliakov [34, p. 29, 117] is convinced that the term «criminal (triable) misconduct» is inappropriate, and considers the term «criminal offense» to be the most justified, since the word «misconduct» indicates the connection with other types of offenses and the part «criminal» is connected with the crime. According to its properties, criminal misconduct, according to the scientist, is an intermediate act between a crime and an administrative offense, the committing of which results in criminal responsibility.

These statements are undoubtedly worthy of attention, since they distinguish from the multifaceted and contradictory subject of knowledge the characteristic features inherent in one phenomenon - criminal misconduct, and start a new legal institute in the science of criminal law that needs theoretical substantiation.

Therefore, comprehension of some types of crimes and criminal activity from the former formal-dogmatic position is impossible, since there comes the period of a new vision of problems and ways of neutralizing the consequences of illegal activity [35, p. 5-8]. In adhering to this position, scientists point to the fact that there are no traits of criminal offense in criminal activity.

Criminal misconduct, according to A. S. Makarenko [36], is a type of criminal offense and is a non-criminal criminal act.

L. Pavlyk [31], considering the concept of «offense» as «an act that violates any norms, rules of conduct, generally accepted procedure, guilt», defines the concept of «criminal misconduct» as an act that violates criminal law, and concludes that the two concepts are different in content and not inherent in the criminal nature of criminal misconduct. But such a judgment in our opinion is not acceptable.

Confirmation of the criminal nature is the adoption of the Law of Ukraine «On Amendments to Certain Legislative Acts of Ukraine on Simplifying the Pre-trial Investigation of Certain Categories of Criminal Offenses» (№7279-Д) [37] on November 22, 2018 by the Verkhovna Rada of Ukraine.

The Act will enter into force on January 1, 2020 and will enact provisions on the settlement of criminal offenses, granting that category the status of a criminal offense for which criminal liability is provided, taking into account at the same time the distinguishing criteria - the degree of public danger, type and way of punishment. According to the provisions of the Law, a «criminal offense» is an action (action or omission) provided by the Criminal Code, which imposes a basic penalty of not more than three thousand nontaxable minimum incomes or other punishment unrelated to deprivation.

\section{References}

1. Кримінальний процесуальний кодекс України : Закон України від 13 квіт. 2012 p. № 4651-VI. Відом. Верховної Ради Украӥни. 2013. № 9-10, № 11-12, № 13. Ст. 88.

2. Етимологічний словник української мови : у 7 т. / голов. ред. О. С. Мельничук. Київ. : Наук. думка, 1985. Т. 2 : Д-Копці. 523 с. Т. $3.744 \mathrm{c}$.

3. Словник української мови : у 11 т. / за ред. І. К. Білодіда. Київ : Наук. думка, 1970-1980.

4. Глинский Я. И. Криминология. Теория, история, эмпирическая база, социальный контроль : курс лекций. СПб. : Юрид. центр Пресс, 2009. 507 с.

5. Карпец И. И. Преступность как реальность. Вопр. филос. М., 1989. № 5. С. 87-89.

6. Про заборону абортів, збільшення матеріальної допомоги породіллям, встановлення державної допомоги багатодітним, розширення мережі пологових будинків, дитячих садків, посилення кримінального покарання за несплату аліментів і про деякі зміни законодавства про шлюб та сім'ю : постанова ЦВК і РНК СРСР від 27 черв. 1936 р.

7. Об отмене уголовной ответственности беременных женщин за производство абортов : указ Президента Верховного Совета СССР от 5 авг. 1954 г. №15. Ведом. Верховного Совета СССР. 1954. № 15. C. 334.

8. Об отмене запрещения абортов : указ Президиума Верховного Совета СССР от 23 ноябр. 1955 г. № 22. Ведом. Верховного Совета СССР. 1955. № 22. Ст. 425.

9. Про внесення змін до Кримінального кодексу України щодо вдосконалення відповідальності за торгівлю людьми та втягнення в заняття проституцією : Закон України 
від 12 січ. 2006 р. № 3316-IV. URL : http://zakon2.rada.gov.ua/laws/show/3316-15.

10. Дурманов Н. Д. Понятие преступления ; отв. ред. М. Д. Шаргородский. М. ; Л. : Издательство АН СССР, 1948. 131 с.

11. Ковалев М. И. Понятие преступления в советском уголовном праве. Свердловск : Издательство Урал. ун-та, 1987. 213 с.

12. Кудрявцев В. Н. Что такое преступление. М. : Госюриздат, 1959. 48 с.

13. Брайнін Я. М. Основні питання складу злочину. Київ : Вища шк., 1959. 239 с.

14. Карпушин М. П., Курляндский В. И. Уголовная ответственность и состав преступления.

М. : Юр. лит., 1974. 231 с.

15. Шишов О.Ф. Преступление и административный проступок. М. : МВССО СССР, Всесоюз. юрид. заоч. ин-т, 1967. 67 с.

16. Турецкий М. Преступление и дисциплинарный проступок. Сои. законность. М., 1956. № 10. C. $15-20$.

17. Сахаров А. Разграничение преступлений и иных правонарушений. Соц. законность. 1974. № 7. C. 32-35.

18. Мельникова Ю. Б. Дифференциация ответственности и индивидуализация наказания. Красноярск : Издательство Краснояр. гос. ун-та, 1989. 121 с.

19. Актуальні проблеми держави і права : зб. наук. пр. / редкол. : С. В. Ківалов (голов. ред.) та ін. ; відп. за вип. В. М. Дрьомін. Одеса : Юрид. літ-ра, 2013. Вип. 69. С. 7-18.

20. Словник української мови : у 4-х т. / за ред. Б. Грінченка. Київ, 1907-1909. Т. 1 ; Т. 3. URL : http//r2u.org.ua/.

21. Словник української мови : у 11 т. / за ред. І. К. Білодіда. Київ : Наук. думка, 19701980. Т. $7.724 \mathrm{c}$.

22. Новий тлумачний словник української мови : у 4 т. / уклад. В. Яременко, О. Сіпушко. Київ : Аконіт, 1998. Т. 3 : О - Р. 927 с.

23. Бачинин В. А., Сальников В. П. Философия права: краткий словарь. СПб. : СПбУ МВД РФ ; Лань, 2000. 382 с.

24. Юридична енциклопедія : у 6 т. / редкол.: Ю. С. Шемшученко (голова редкол.) та ін. Київ : Укр. енцикл., 1998. Т. 5 : П- С, 2003. 736 с.

25. Копєйчиков В. В. Правознавство : підруч. 7-е вид., стер. Київ : Юрінком Інтер, 2003. 736 с.

26. Скакун О. Ф. Теорія держави і права : підручник. Харків : Консум, 2001. 656 с.

27. Пєтков С. В. До питання про співвідношення дефініцій «публічний проступок» та «адміністративний проступок». Юрид. журн. 2010. № 9. URL : http:// justinian.com.ua/print.php?id=3695.

28. Голосніченко І. П. Адміністративне законодавство - нові підходи до кодифікації. Вісн. Луган. держ. ун-ту внутр. справ ім. Е. О. Дідоренка. 2008. № 6, ч. 1. С. 68-76. (Спецвип.).

29. Манжула А. А. Дефініція «проступок» як категорія публічно-правової відповідальності. Форум права. 2011. № 3. С. 505-511. URL : http://www.nbuv.gov.ua/ e-journals/FP/20113/11maappv.pdf.

30. Кашкаров О. О. Передумови реформування Кримінального кодексу України та створення законодавства про кримінальні проступки. Форум права. 2009. № 1. С. 236-241. URL : http://nbuv.gov.ua/j-pdf/ FP_index.htm_2009_1_36.pdf.

31. Павлик Л. В. Перспективи виділення категорії кримінального проступку за злочинні посягання у сфері економіки. Форум права. 2012. № 2. С. 524-531. URL : http://www.nbuv.gov.ua/ejournals/FP/2012-2/12plvuce.pdf.

32. Кос О. Д. Кримінальний проступок як структурний елемент політики у сфері боротьби зі злочинністю. Вісн. Луган. держ. ун-ту внутр. справ ім. Е. О. Дідоренка. 2011. № 5. С. 130-134. (Спецвип.).

33. Фріс П. Л. Злочин і кримінальна провина : проблеми нормативного закріплення. Право України. 2011. С. 42-49.

34. Кримінальний проступок у доктрині і законодавстві : монографія / авт. кол. : В. О. Туляков, Г. П. Пімонов, Н. І. Мітріцан [та ін.] ; за заг. ред. В. О. Тулякова. Одеса : Юрид. літ., 2012. $424 \mathrm{c}$.

35. Философия уголовного права / сост. Ю. В. Голик, А. Ю. Голик ; под ред. Ю. В. Голика. СПб. : Юрид. центр Пресс, 2004. 348 с.

36. Макаренко А. С. Щодо правової природи кримінального проступку. URL : http://lawdep.pu.if.ua/conference2014/articles/makarenko.pdf.

37.Про внесення змін до деяких законодавчих актів України щодо спрощення досудового розслідування окремих категорій кримінальних правопорушень: Закон України від 22 листопада 2018 р. № 7279-д. URL : http://w1.c1.rada.gov.ua/pls/zweb2/webproc4_1?pf3511=63928].

Received to editorial office 03.12.2019

1. Kryminalnyi protsesualnyi kodeks Ukrainy [Criminal Procedural Code of Ukraine]: Zakon Ukrainy vid 13 kvit. 2012 r. № 4651-VI // Vidom. Verkhovnoi Rady Ukrainy. 2013. № 9-10, № 11-12, № 13. St. 88. [in Ukr.]

2. Etymolohichnyi slovnyk ukrainskoi movy [The etymological dictionary of the Ukrainian language]: u 7 t. / holov. red. O. S. Melnychuk. Kyiv : Nauk. dumka, 1985. T. 2 : D-Koptsi. 523 s. [in Ukr.] 
3. Slovnyk ukrainskoi movy [Dictionary of the Ukrainian language]: u 11 t. / za red. I. K. Bilodida. Kyiv : Nauk. dumka, 1970-1980. T. 3. 744 s. [in Ukr.]

4. Glynskyi, Ya. I. (2009) Krymynologiya. Teoriya, istoriya, empiricheskaya baza, sotsyalnyi kontrol [Criminology. Theory, history, empirical basis, social control]: kurs lektsiy. SPb. : Yuryd. tsentr Press, 507 s. [in Russ.] [in Russ.]

5. Karpets, I. I. (1989) Prestupnost kak realnost [Crime as a reality]. Vopr. fylos. M., № 5. S. 87-89.

6. Pro zaboronu abortiv, zbilshennia materialnoyi dopomohy porodilliam, vstanovlennia derzhavnoi dopomohy bahatoditnym, rozshyrennia merezhi polohovykh budynkiv, dytiachykh sadkiv, posylennia kryminalnoho pokarannia za nesplatu alimentiv i pro deiaki zminy zakonodavstva pro shliub ta simiu [On prohibition of abortion, increase in maternity assistance, establishment of state aid for large children, expansion of maternity hospitals, kindergartens, increased criminal penalties for non-payment of alimony, and some changes to the law on marriage and family]: postanova TsVK i RNK SRSR vid 27 cherv. 1936 r. [in Ukr.]

7. Ob otmene ugolovnoy otvetstvennosty beremennykh zhenshchyn za proizvodstvo abortov [On abolition of criminal liability of pregnant women for abortions]: ukaz Prezydenta Verkhovnoho Soveta SSSR ot 5 avg. 1954 g. № 15. Vedom. Verkhovnogo Soveta SSSR. 1954. № 15. S. 334. [in Russ.]

8. Ob otmene zapreshcheniya abortov [On abolition of abortion ban]: ukaz Prezidiuma Verkhovnogo Soveta SSSR ot 23 noyabr. 1955 g. № 22. Vedom. Verkhovnogo Soveta SSSR. 1955. № 22. St. 425. [in Russ.]

9. Pro vnesennia zmin do Kryminalnoho kodeksu Ukrainy shchodo vdoskonalennia vidpovidalnosti za torhivliu liudmy ta vtiahnennia v zaniattia prostytutsiieiu [On Amendments to the Criminal Code of Ukraine on Improving Responsibility for Trafficking in Human and Involving in Prostitution]: Zakon Ukrainy vid 12 sich. 2006 r. № 3316-IV. URL : http://zakon2.rada.gov.ua/laws/show/3316-15. [in Ukr.]

10. Durmanov, N. D. (1948) Poniatiye prestupleniya [The concept of crime]; otv. red. M. D. Shargorodskyi. M. ; L. : Izdatelstvo AN SSSR, 131 s. [in Russ.]

11. Kovalev, M. I. (1987) Poniatye prestuplenyia v sovetskom ugolovnom prave [The concept of crime in the Soviet criminal law]. Sverdlovsk : Izdatelstvo Ural. un-ta, 213 s. [in Russ.] [in Russ.]

12. Kudryavtsev, V. N. (1959) Chto takoye prestupleniye [What is a crime]. M. : Gosyurizdat, $48 \mathrm{~s}$.

13. Braynin, Ya. M. (1959) Osnovni pytannya skladu zlochynu [The main issues of corpus delicti]. Kyiv : Vyshcha shk., 239 s. [in Ukr.]

14. Karpushyn, M. P., Kurlyandskiy, V. I. (1974) Ugolovnaya otvetstvennost i sostav prestupleniya [Criminal liability and corpus delicti]. M. : Yur. lit., 231 s. [in Russ.]

15. Shyshov, O. F. (1967) Prestupleniye i administrativnyy prostupok [Crime and administrative misconduct]. M. : MVSSO SSSR, Vsesoyuz. yurid. zaoch. in-t, 67 s. [in Russ.]

16. Turetskiy, M. (1956) Prestupleniye i distsiplinarnyy prostupok [Crime and disciplinary misconduct]. Sots. zakonnost. M., № 10. S. 15-20. [in Russ.]

17. Sakharov, A. (1974) Razgranicheniye prestupleniy i inykh pravonarusheniy [Differentiation of crimes and other offenses]. Sots. zakonnost. № 7. S. 32-35. [in Russ.]

18. Melnikova, Yu. B. (1989) Differentsiatsiya otvetstvennosti i individualizatsiya nakazaniya [Differentiation of crimes and other offenses]. Krasnoyarsk : Izdatelstvo Krasnoyar. gos. un-ta, 121 s. [in Russ.]

19. Aktualni problemy derzhavy i prava [Actual problems of state and law]: zb. nauk. pr. / redkol. : S. V. Kivalov (holov. red.) ta in. ; vidp. za vyp. V. M. Dromin. Odesa : Yuryd. lit-ra., 2013. Vyp. 69. S. 7-18. [in Ukr.]

20. Slovnyk ukrainskoyi movy [Dictionary of the Ukrainian language]: u 4-kh t. / za red. B. Hrinchenka. Kyiv, 1907-1909- T. 1 ; T. 3. URL : http//r2u.org.ua/.[in Ukr.]

21. Slovnyk ukrainskoyi movy [Dictionary of the Ukrainian language]: u $11 \mathrm{t}$. / za red. I. K. Bilodida. Kyiv : Nauk. dumka, 1970-1980. T. 7. 724 s. [in Ukr.]

22. Novyi tlumachnyi slovnyk ukrainskoi movy [New Interpretative Dictionary of the Ukrainian Language]: u 4 t. / uklad. V. Yaremenko, O. Sipushko. K. : Akonit, 1998. T. 3 : O - R. 927 s. [in Ukr.]

23. Bachinin, V. A., Salnikov, V. P. (2000) Filosofiya prava : kratkiy slovar [Philosophy of Law: A Concise Dictionary]. SPb. : SPbU MVD RF ; Lan,. 382 s. [in Russ.]

24. Yurydychna entsyklopediya [Legal Encyclopedia]: u 6 t. / redkol.: Yu. S. Shemshuchenko (holova redkol.) ta in. Kyiv : Ukr. entsykl., 1998. T. 5 : P-S, 2003. 736 s. [in Ukr.]

25. Kopeychikov, V. V. (2003) Pravoznavstvo [Jurisprudence]: pidruchnyk. 7-me vyd., ster. Kyiv : Yurinkom Inter, $736 \mathrm{~s}$. [in Ukr.]

26. Skakun, O. F. (2001) Teoriya derzhavy i prava [Theory of State and Law]: pidruchnyk. Kharkiv : Konsum, $656 \mathrm{~s}$. [in Ukr.]

27. Pietkov, S. V. (2010) Do pytannia pro spivvidnoshennia definitsii «publichnyi prostupok» ta «administratyvnyi prostupok» [On the question of the relation between the definitions of "public misconduct" and "administrative misconduct"]. Yuryd. zhurn. № 9. URL : http:// justinian.com.ua/print.php?id=3695. [in Ukr.]

28. Holosnichenko, I. P. (2008) Administratyvne zakonodavstvo - novi pidkhody do kodyfikatsii [On the question of the relation between the definitions of "public misconduct" and "administrative misconduct”]. Visn. Luhan. derzh. un-tu vnutr. sprav im. E. O. Didorenka. № 6, ch. 1. S. 68-76. (Spetsvyp.). [in Ukr.]

29. Manzhula, A. A. (2011) Definitsiya «prostupok» yak katehoriia publichno-pravovoyi 
vidpovidalnosti [Definition of "misconduct" as a category of public liability]. Forum prava.. № 3. S. 505511. URL : http://www.nbuv.gov.ua/ e-journals/FP/2011-3/11 maappv.pdf. [in Ukr.]

30. Kashkarov, O. O. (2009) Peredumovy reformuvannia Kryminalnoho kodeksu Ukrainy ta stvorennia zakonodavstva pro kryminalni prostupky [Prerequisites for reforming the Criminal Code of Ukraine and creating legislation on criminal offenses]. Forum prava. № 1. S. 236-241. URL : http://nbuv.gov.ua/j-pdf/FP_index.htm_2009_1_36.pdf. [in Ukr.]

31. Pavlyk, L. V. (2012) Perspektyvy vydilennia katehorii kryminalnoho prostupku za zlochynni posiahannia u sferi ekonomiky [Perspectives of selection of the category of criminal misconduct for criminal assault in the economy]. Forum prava. № 2. S. 524-531. URL : http://www.nbuv.gov.ua/ejournals/FP/2012-2/12plvuce.pdf. [in Ukr.]

32. Kos, O. D. (2011) Kryminalnyi prostupok yak strukturnyi element polityky u sferi borotby zi zlochynnistiu [Criminal misconduct as a structural element of anti-crime policy]. Visn. Luhan. derzh. untu vnutr. sprav im. E. O. Didorenka. № 5. S. 130-134. (Spetsvyp.). [in Ukr.]

33. Fris, P. L. (2011) Zlochyn i kryminalna provyna : problemy normatyvnoho zakriplennia [Crime and criminal misconduct: problems of regulatory fixing]. Pravo Ukrainy.. S. 42-49. [in Ukr.]

34. Kryminalnyi prostupok u doktryni i zakonodavstvi [Criminal misconduct in doctrine and legislation]: monohrafiia / avt. kol. : V. O. Tuliakov, H. P. Pimonov, N. I. Mitritsan [ta in.] ; za zah. red. V. O. Tuliakova. Odesa : Yuryd. lit., 2012. 424 s. [in Ukr.]

35. Filosofiya ugolovnogo prava [Philosophy of criminal law] / sost. Yu. V. Golik, A. Yu. Golik ; pod red. Yu. V. Golika. SPb. : Yuryd. tsentr Press, 2004. 348 s. [in Russ.]

36. Makarenko A. S. Shchodo pravovoyi pryrody kryminalnoho prostupku [On the legal nature of criminal misconduct]. URL : http://law-dep.pu.if.ua/conference2014/articles/makarenko.pdf. [in Ukr.]

37. Pro vnesennia zmin do deiakykh zakonodavchykh aktiv Ukrainy shchodo sproshchennia dosudovoho rozsliduvannia okremykh katehorii kryminalnykh pravoporushen [On amendments to some legislative acts of Ukraine regarding simplification of pre-trial investigation of certain categories of criminal offenses]: Zakon Ukrainy vid 22 lystopada 2018 r. № 7279-d. URL : http://w1.c1.rada.gov.ua/pls/zweb2/webproc4_1?pf3511=63928]. [in Ukr.]

\section{Summary}

In order to determine the criminal nature of the category of criminal offense, the definition of "criminal offense" as a generic (subsidiary) concept is analyzed and the specific (derivative) concepts of "crime" and "criminal offense" are characterized. Awareness of the essence of the phenomenon of "criminal misconduct" in criminal science has been revealed.

Keywords: criminal offense, crime, criminal offense, criminal procedural law, criminal law.

UDC 347.9

DOI 10.31733/2078-3566-2019-5-189-193

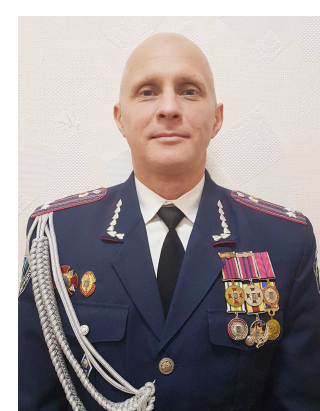

Sergiy BABANIN ${ }^{\circledR}$

Ph.D, Ass. Prof.

(the Dnipropetrovsk State University

of Internal Affairs)

\section{LEGAL PROVISION OF MEDIATION IN UKRAINE}

Сергій Бабанін. ПРАВОВЕ ЗАБЕЗПЕЧЕННЯ МЕДІАЦІї В УКРАЇНІ. Потреба впровадження інституту медіації до правової системи України у цивільний та кримінальний процеси викликана, зокрема, необхідністю розвантаження судової системи України, оскільки завищена кількість справ, які знаходяться в провадженні суддів, не дає можливості здійснювати у повному обсязі належну підготовку та розгляд таких справ. Розглянуті основні положення внесених до Верховної Ради України проектів Закону «Про медіацію» № 2480-1 від 09 квітня 2015 р. та № 3665 від 17 грудня 2015 р. Запропоновані визначення медіації, медіатора, сфери застосування медіації, видів спорів, по яких проведення медіації доцільно встановити обов'язковим, угоди за результатами медіації. Так, під медіацією слід розуміти позасудове врегулювання спору за участю нейтральної сторони - медіатора, який шляхом ведення перемовин зі сторонами спору досягає прийняття цими сторонами взаємовигідного для них рішення.

Медіатором є фізична особа, яка внесена до Сдиного реєстру медіаторів України,

(C) Babanin S., 2019

ORCID iD: https://orcid.org/0000-0002-8424-8825

babanin-s@ukr.net 